\title{
PENDAMPINGAN IBU MENUJU MASYARAKAT SADAR STUNTING DI DESA BAROS KABUPATEN SERANG-BANTEN
}

\author{
Rokhaidah $^{1}$, Herlina ${ }^{2}$, dan Riadinni Alita $^{3}$ \\ ${ }^{1,2,3}$ Program Studi Keperawatan, Universitas Pembangunan Nasional Veteran Jakarta \\ Email: rokhaidah@upnvj.ac.id
}

\begin{abstract}
Community empowerment is an effort to give empowerment or strengthening to the community to find new alternatives to be a better community. Serang Regency is one of the districts that is locus of stunting. The stunting rate in Serang Regency in 2019 is still quite high, 32\%. The four districts in Serang are included in the ten districts which are the locus of stunting, namely Serang, Lebak, Pandegelang and Tangerang districts. The problem found in Baros village is that the growth of children under five is not optimal by the mother and there has never been any training on child growth. Based on this, the service team from the Faculty of Health Sciences at UPN Veteran Jakarta conducted community service in the form of health education on stunting and child growth training with the aim of fostering awareness, willingness, and the ability of mothers to prevent and protect children from stunting. The method of implementing this community service is carried out in several stages, namely: area potential survey, dialogue program activities through FGDs, health promotion, child growth training, and monitoring evaluation. 30 mothers were participating in health promotion and child growth training. The results of this activity obtained data that mothers who have good knowledge of $83.3 \%$ and sufficient knowledge of $26.7 \%$ and skills of mothers in the environment of child growth $46.7 \%$ have good skills and $53.3 \%$ of sufficient skills. Continuous efforts are needed to increase children's growth independently so that the incidence of stunting can be detected early.
\end{abstract}

Keywords: Children, Community, Mentoring, Mother, Stunting Aware.

\begin{abstract}
ABSTRAK
Pemberdayaan masyarakat adalah upaya memberikan daya (empowerment) atau penguatan (strengthening) kepada masyarakat untuk menemukan alternatif-alternatif baru dalam pembangunan masyarakat sehingga terwujud kehidupan masyarakat yang lebih baik. Kabupaten serang adalah salah satu kabupaten yang menjadi lokus stunting. Angka stunting di Kabupaten Serang pada tahun 2019 masih cukup tinggi yaitu 32\%. Empat kabupaten di Serang masuk dalam sepuluh kabupaten di seluruh Indonesia yang menjadi lokus stunting yaitu kabupaten Serang, Lebak, Pandegelang dan Tangerang. Hasil observasi yang dilakukan diketahui bahwa permasalahan di desa Baros adalah belum optimalnya pemantauan pertumbuhan balita secara mandiri oleh ibu dan belum pernah dilakukan pelatihan pemantauan pertumbuhan anak. Berdasarkan hal tersebut maka tim pengabdi dari Fakultas Ilmu Kesehatan UPN Veteran Jakarta melakukan pengabdian kepada masyarakat berupa pendidikan kesehatan tentang stunting dan pelatihan pemantauan pertumbuhan anak dengan tujuan untuk menumbuhkan kesadaran, kemauan, dan kemampuan ibu dalam mengenali, mencegah dan melindungi anak dari penyakit stunting. Metode pelaksanaan pengabdian masyarakat ini dilakukan melalui beberapa tahap yaitu: Survei potensi wilayah, dialog program kegiatan melalui FGD, promosi kesehatan, pelatihan pemantauan pertumbuhan anak, dan monitoring evaluasi. Kegiatan promosi kesehatan dan pelatihan pemantauan pertumbuhan anak diikuti oleh $30 \mathrm{ibu}$ balita. Hasil dari kegiatan ini diperoleh data bahwa ibu yang memiliki pengetahuan baik $83 \%$ dan pengetahuan cukup $27 \%$ dan keterampilan ibu dalam pemantauan pertumbuhan anak $47 \%$ berketerampilan baik dan 53\% keterampilan cukup. Diperlukan upaya berkelanjutan berupa pendampingan ibu balita untuk tetap meningkatan keterampilan pemantauan pertumbuhan anak secara mandiri sehingga kejadian stunting dapat dideteksi secara dini.
\end{abstract}

Kata Kunci: Anak, Ibu, Pendampingan, Masyarakat, Sadar Stunting

\section{PENDAhuluan}

Pemberdayaan masyarakat adalah upaya memberikan daya (empowerment) atau penguatan (strengthening) kepada masyarakat untuk menemukan alternatif-alternatif baru dalam pembangunan masyarakat dan memiliki tujuan diantaranya adalah perbaikan kehidupan berupa memperbaiki keadaan kehidupan setiap keluarga dan masyarakat serta perbaikan masyarakat berupa dukungan lingkungan (fisik dan sosial) yang baik sehingga terwujud kehidupan masyarakat yang lebih baik (Mardikanto, 2014). Menurut Undang-Undang No. 6 Tahun 2014 tentang Desa, Pemberdayaan masyarakat desa didefinisikan sebagai upaya mengembangkan kemandirian dan kesejahteraan masyarakat dengan meningkatkan pengetahuan, sikap, keterampilan, perilaku, 
kemampuan, kesadaran, serta memanfaatkan sumber daya melalui penetapan kebijakan, program, kegiatan, dan pendampingan yang sesuai dengan esensi masalah dan prioritas kebutuhan masyarakat desa.

Lingkup kegiatan pemberdayaan masyarakat desa, diatur dalam Peraturan Menteri Dalam Negeri No.114 Tahun 2014 pada pasal 6 diantaranya adalah peningkatan kapasitas masyarakat, antara lain: kader pemberdayaan masyarakat Desa dan kelompok pemerhati dan perlindungan anak. Pemberdayaan Masyarakat Desa berlandaskan pada asas pemberdayaan, yaitu upaya meningkatkan taraf hidup dan kesejahteraan masyarakat desa melalui penetapan kebijakan, program, dan kegiatan yang sesuai dengan esensi masalah dan prioritas kebutuhan masyarakat desa.

Desa Baros merupakan desa yang terletak di kabupaten Serang dan lokasinya yang sangat strategis tidak jauh dari pusat kota serang dan pusat kota pandeglang, Luas Wilayah Desa Baros adalah 282 Ha, jumlah penduduk 6.557 yang terdiri dari 1980 Kepala Keluarga. Tingkat pendidikan masyarakat Desa Baros dengan tamat SD 16,11\%, tamat SMP 14,22\%, tamat SMA 20,35\% dan tamat Perguruan Tinggi 2,91\%. Lembaga kemasyarakatan Posyandu 6 kelompok dan PKK 1 kelompok. Jumlah anak usia 4-6 tahun adalah 240 anak. Desa Baros terbagi dalam 6 RW dan 23 RT. Peta wilayah Desa Baros dapat dilihat pada Gambar 1.

Kabupaten serang adalah salah satu kabupaten yang menjadi lokus stunting. Angka stunting di Kabupaten Serang pada tahun 2019 masih cukup tinggi yaitu 32\%. Empat kabupaten di Serang masuk dalam sepuluh kabupaten di seluruh Indonesia yang menjadi lokus stunting yaitu kabupaten Serang, Lebak, Pandegelang dan Tangerang (Faqih, 2019).

Berdasarkan hasil observasi yang dilakukan diketahui bahwa permasalah an terkait kesehatan anak di Posyandu Arjuna desa Baros adalah ibu balita belum mengetahui tentang masalah stunting pada anak dan masih terdapat 5 dari balita dengan status gizi kurang, masalah gizi kurang merupakan faktor risiko untuk kejadian stunting. Penyebab dari masalah kesehatan ini diantaranya adalah belum optimalnya pemantauan pertumbuhan balita oleh ibu di posyandu maupun secara mandiri dan belum terbentuknya pemahaman ibu tentang pencegahan stunting.

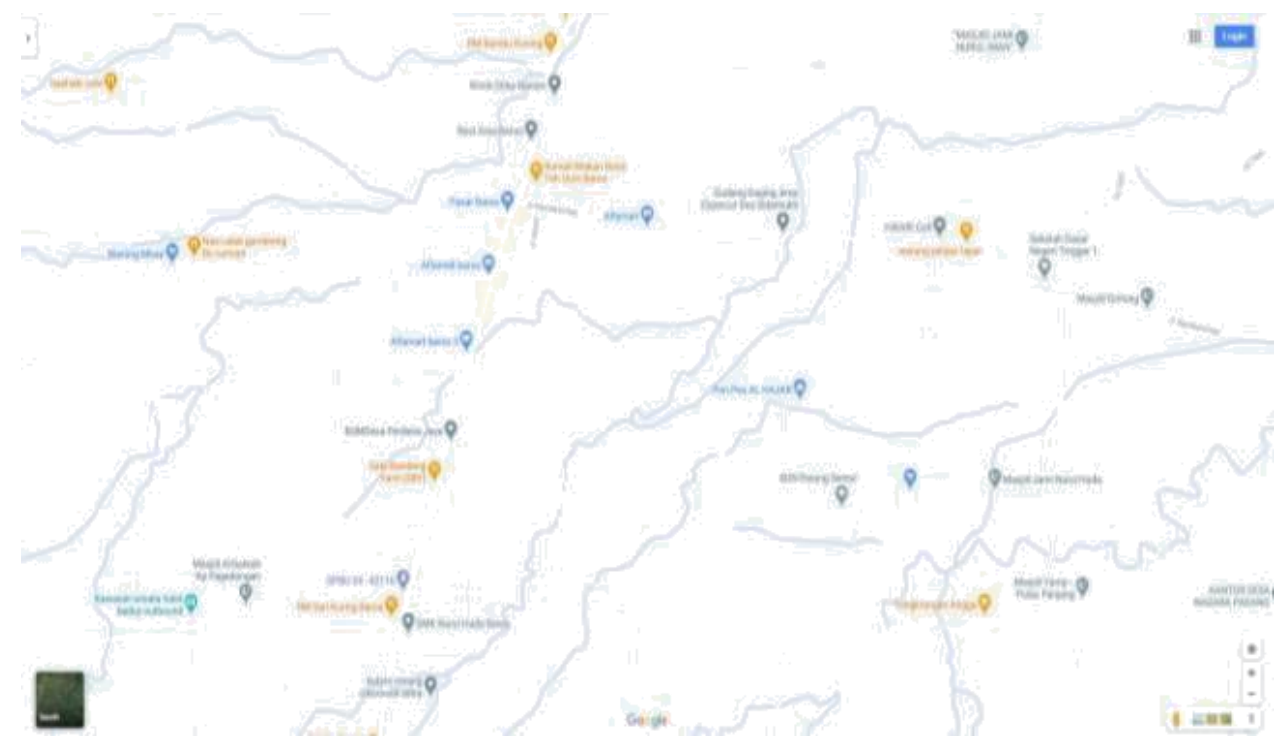

Gambar 1: Peta wilayah Desa Baros 


\section{METODE PELAKSANAAN PKM}

Berdasarkan permasalahan yang dihadapi masyarakat desa Baros maka tim pengabdi dari Fakultas Ilmu Kesehatan UPN Veteran Jakarta mengadakan kegiatan Pengabdian Masyarakat (Abdimas) berupa promosi kesehatan tentang stunting dan pelatihan pemantauan pertumbuhan anak. Kegiatan ini diikuti oleh 30 ibu yang memiliki anak balita di Posyandu Arjuna desa Baros.

Luaran dari kegiatan ini adalah pemberian promosi kesehatan dan pelatihan pemantauan pertumbuhan anak berupa pelatihan cara pengukuran tinggi badan anak dengan menggunakan alat ukur yang sesuai untuk meningkatkan pemahaman ibu tentang penyakit stunting meliputi definisi stunting, penyebab, tanda gejala dan cara pencegahan stunting. Serta untuk membentuk keterampilan ibu dalam pemantauan pertumbuhan anak di Posyandu Arjun desa Baros.

Paparan kegiatan pengabdian ini disampaikan di kantor kecamatan baros dan kepala lurah desa Baros. Selanjutnya dilakukan koordinasi dengan kader posyandu Arjuna untuk mendaftar ibu yang memiliki balita dan bisa mengikuti kegiatan ini. Kegiatan dilaksanakan pada hari Rabu, 13 Agustus 2020 bertempat di rumah bapak RT 07 desa Baros Kelurahan Baros, pukul 08.00-14.00 WIB.

Kegiatan promosi kesehatan tentang stunting pada anak disampaian dengan metode ceramah dan diskusi serta Tanya jawab meliputi materi tentang fakta stunting, penyebab, gejala stunting, dampak stunting dan cara pencegahan stunting. Sebelum penyampaian materi dilakukan pretest tentang materi stunting. Peserta kegiatan diberikan kwesioner dan alat tulis untuk menjawab pertanyaan pretest. Materi promosi kesehatan diberikan dengan bantuan media power pint dan proyektor. Setelah selesai materi, peserta kegiatan dilakukan post test dengan pertanyaan yang sama saat pre test. Pendidikan kesehatan mengenai pemantauan pertumbuhan anak merupakan tindakan promosi yang penting untuk deteksi awal masalah pertumbuhan anak (Dagne et al., 2020). Pemantauan pertumbuhan adalah proses memantau dan menilai tingkat pertumbuhan anak dibandingan dengan standar pengukuran antropometri secara berkala dan sering (Daniel et al., 2017). Pemantauan pertumbuhan anak secara rutin harus dilakukan terutama untuk anak di bawah usia dua tahun. Sebagai penyaringan dan pemantauan tumbuh kembang anak karena dapat mempengaruhi pencapaian potensi anak. Promosi tentang tumbuh kembang anak dan kesadaran mengenai tumbuh kembang anak kepada semua orang tua dan praktisi kesehatan sangat penting (Tengkawan et al., 2020).

Tahap Pelatihan dilakukan dengan melatih peserta tentang cara pemeriksaan pertumbuhan anak. Peserta dibagi menjadi kelompok-kelompok kecil, tiap kelompok terdiri dari 5-6 orang. Pengabdi melakukan demontrasi prosedur cara mengukur tinggi badan anak ataupun cara mengukur panjang badan anak dan menghitung usia kronologis. setelah prosedur menggukur tingggi badan maupun panjang badan anak dan menentukan usia anak, prosedur berikutnya adalah menentukan status katagori gizi anak apakah masuk katagori stunting atau normal. Pengabdi mengajarkan pemantauan stunting dengan menggunakan Standar Antropometri Penilaian Status Gizi Anak dari Kementerian Kesehatan Republik Indonesia tahun 2011. Semua kegiatan pengabdian ini dilakukan dengan menerapkan protokol kesehatan pencegahan penyebaran virus covid-19.

\section{HASIL DAN PEMBAHASAN}

Kegiatan promosi kesehatan dan pelatihan pemantauan pertumbuhan anak dilaksanakan di rumah ketua RT yang beralamat di Jalan Baros Petir, Kecamatan Baros, Kabupaten Serang, Kota Banten. Peserta yang hadir saat kegiatan ini adalah 30 orang ibu balita dan didampingi 3 kader posyandu. Peserta merupakan ibu balita di posyandu Arjuna desa Baros.

Jumlah keseluruhan balita di Posyandu 110 balita. Peserta adalah ibu yang memiliki anak berusia 1 bulan sampai 60 bulan. Rata-rata usia ibu yang memiliki balita di Posyandu Arjuna desa Baros adalah 32 tahun, dengan usia paling muda adalah 20 tahun dan usia paling tua adalah 44 tahun. 
Kisaran umur 21-40 tahun masuk kedalam tahap usia dewasa awal. Masa dewasa adalah masa awal menyesuaikan diri terhadap pola-pola kehidupan baru dan harapan-harapan social baru. Pada masa ini nilai yang dimiliki seeorang yang telah dewasa dapat berubah karena pengalaman dan semakin luasnya hubungan social sehingga meningkatkan kesadaran positif (Yudrik Jahja, 2015).

Latar belakang pendidikan ibu balita di Posyandu Arjuna adalah $85 \%$ pendidikan menengah, 8,3\% pendidikan tinggi dan $6,7 \%$. Pendidikan sangat terkait dengan tingkat pengetahuan kesehatan, dan berhubungan positif dengan gaya hidup sehat. Pendidikan juga berpengaruh terhadap perilaku kesehatan (Hoffmann \& Lutz, 2019). Rata-rata usia balita di posyandu Arjuna desa Baros adalah 22 bulan dengan usia termuda adalah 1 bulan dan tertua 53 bulan. Di negara berkembang anakanak umur 0-5 tahun merupakan golongan yang paling rawan terhadap masalah gizi (Hartono, 2016). Gizi yang buruk selama periode pertumbuhan dan perkembangan yang signifikan dan sepanjang hidup berdampak pada hasil kesehatan jangka panjang; meningkatkan prevalensi penyakit tidak menular, biaya perawatan kesehatan, dan beban penyakit; dan berdampak negatif terhadap produktivitas ekonomi dan manusia (Devine \& Lawlis, 2019).

Hasil data pengetahuan dan keterampilan ibu pada saat post test adalah ibu yang memiliki pengetahuan baik $83 \%$ dan pengetahuan cukup $27 \%$ dan keterampilan ibu dalam pemantauan pertumbuhan anak $47 \%$ berketerampilan baik dan $53 \%$ keterampilan cukup. Pada kegiatan ini peserta juga diajarkan cara menganalisis hasil status gizi anak dengan menggunakan aplikasi yang bisa di download melalu smart phone android. Aplikasi yang digunakan adalah "kalkulator gizi anak". Aplikasi ini dapat menentukan status gizi anak berdasarkan berat badan menurut umur $(\mathrm{BB} / \mathrm{U})$, tinggi badan menurut umur $(\mathrm{TB} / \mathrm{U})$, berat badan menurut tinggi badan $(\mathrm{BB} / \mathrm{TB})$, dan indeks masa tubuh menurut umur (IMT/U) sesuai dengan standar antropometri penilaian status gizi anak dari Kementerian Kesehatan RI tahun 2011 yang juga mengacu pada standar Word Health Organization (WHO). Katagori dan ambang batas status gizi anak berdasarkan indeks dapat dibedakan menjadi katagori gizi buruk, gizi kurang, gizi baik, gizi lebih, sangat pendek, pendek, normal dan tinggi (Kementerian Kesehatan RI, 2011).

Adanya pandemi Covid-19 mengakibatkan pembatasan kegiatan sosial masyarakat yang berdampak pada perubahan pola sosial ekonomi. Akses konsumsi dan pelayanan kesehatan yang terbatas berpengaruh terhadap penurunan status gizi anak, sehingga meningkatkan risiko prevalensi stunting. Gambaran prevalensi stunting dan wasting di daerah yang terkonfirmasi kasus Covid-19 cenderung tinggi sehingga perlu dilakukan tindakan untuk mencegah meluasnya masalah kesehatan pada anak (Kementerian Kesehatan RI, 2020). Kegiatan pengabdian ini sesuai dengan kebutuhan masyarakat untuk mencegah meningkatnya kejadian stunting sebagai akibat tidak langsung dari pandemic covid-19. Karakteristik peserta kegiatan dan karakteristik balita di posyandu Arjuna dapat dilihat pada Tabel 1.

Kegiatan monitoring dan evaluasi dilakukan bersama oleh tim pengabdi dan mitra untuk mengukur keberhasilan program pengabdian, evaluasi dilakukan satu bulan setelah kegiatan penyuluhan, mitra dalam hal ini kader posyandu melakukan evaluasi terhadap kemampuan orang tua dalam mengukur tinggi badan anak dan memantau pertumbuhan anak dengan menggunakan aplikasi di HP android, kader melaporkan hasil evaluasi bahwa ibu balita melakukan pemantauan pertumbuhan anaknya dengan cara seperti yang telah tim pengabdi ajarkan. Dampak dari pelatihan pemantauan pertumbuhan anak ini menjadikan ibu balita memahami pentingnya pemantauan pertumbuhan anak dan mampu menggunakan teknologi informasi yang tersedia dalam inovasi pemantauan pertumbuhan anak. Dokumentasi pelaksanaan kegiatan dapat dilihat pada Gambar 2 dan Gambar 3. 
Tabel 1. Karakteristik Ibu dan Balita di Posyandu Arjuna Desa Baros

\begin{tabular}{|c|c|c|}
\hline No & Karakteristik & $\%$ \\
\hline \multirow[t]{4}{*}{1} & Usia Ibu & \\
\hline & - 20-30 tahun & $36 \%$ \\
\hline & - $31-40$ tahun & $57 \%$ \\
\hline & - $>41$ tahun & $7 \%$ \\
\hline \multirow[t]{4}{*}{2} & Usia Balita & \\
\hline & - $1-12$ bulan & $12 \%$ \\
\hline & - $13-36$ bulan & $64 \%$ \\
\hline & - $37-60$ bulan & $24 \%$ \\
\hline \multirow[t]{4}{*}{3} & Pendidikan ibu & \\
\hline & - Pendidikan tinggi & $8 \%$ \\
\hline & - Pendidikan menegah & $85 \%$ \\
\hline & - Pendidikan rendah & $7 \%$ \\
\hline \multirow[t]{3}{*}{4} & Pengetahuan Ibu & \\
\hline & - Pengetahuan baik & $83 \%$ \\
\hline & - Pengetahuan cukup & $27 \%$ \\
\hline \multirow[t]{3}{*}{5} & Keterampilan Ibu & \\
\hline & - Keterampilan baik & $47 \%$ \\
\hline & - Keterampilan cukup & $53 \%$ \\
\hline
\end{tabular}
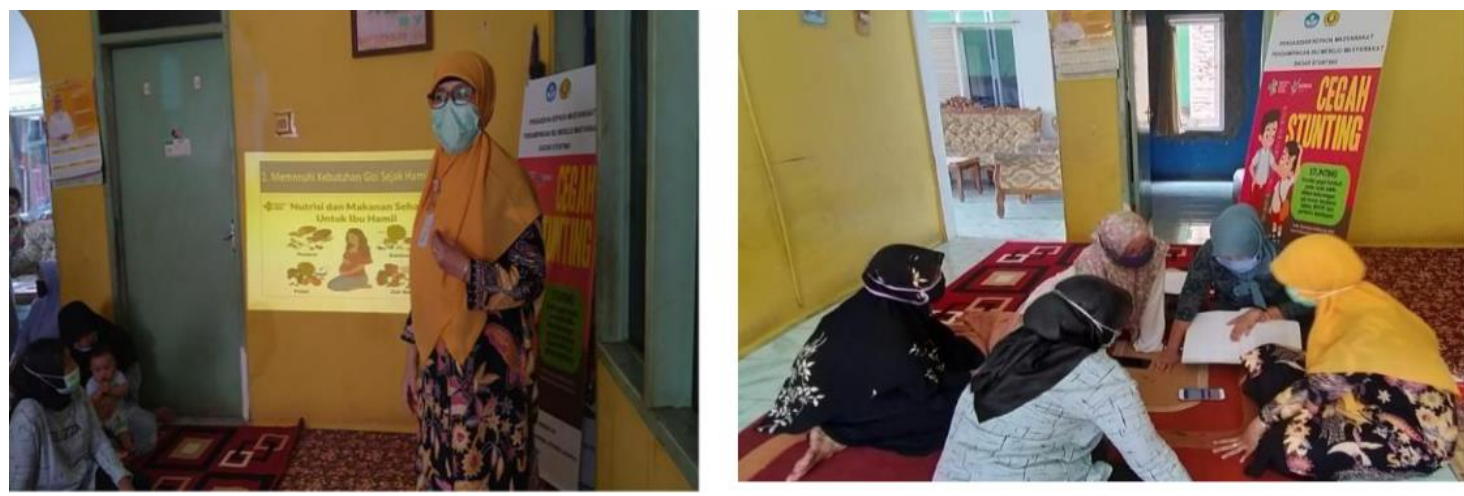

Gambar 2: Kegiatan Pendampingan Ibu Balita

Sumber: dokumentasi pribadi pengabdi, 2020

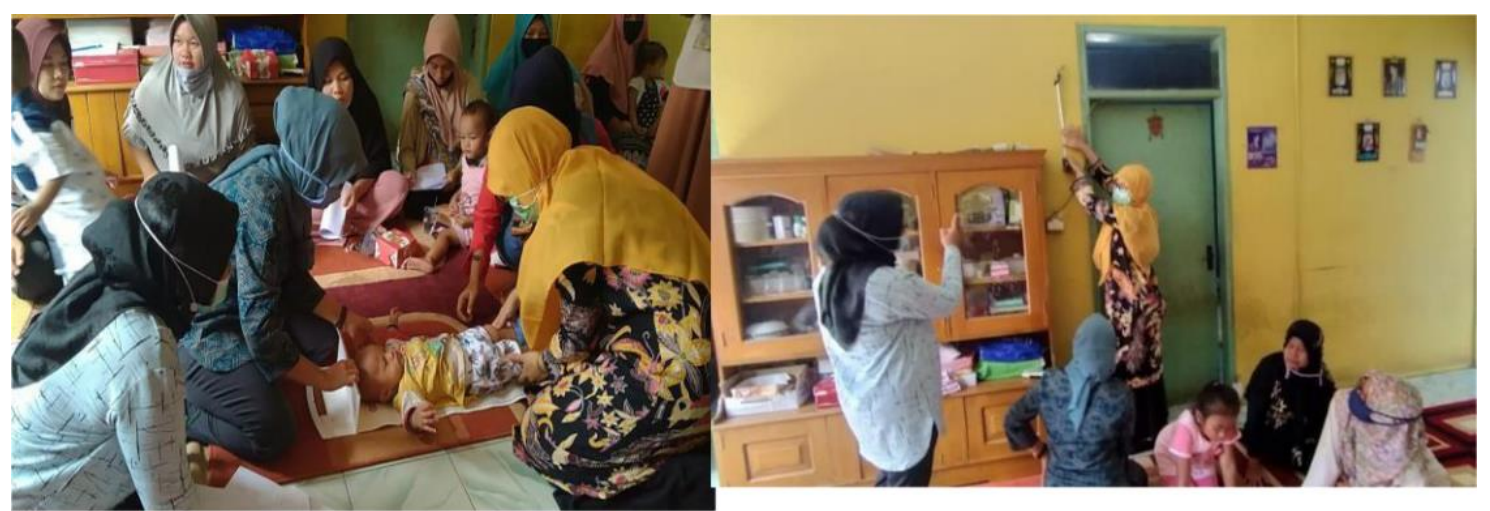

Gambar 3: Demonstrasi Cara Pengukuran Tinggi/Panjang Badan Bayi dan Cara Pemantauan Pertumbuhan Anak

Sumber: dokumentasi pribadi pengabdi, 2020 


\section{KESIMPULAN DAN SARAN}

Kegiatan pendampingan ibu menuju masyarakat sadar stunting yang telah dilakukan di Desa Baros, Kecamatan Baros, Kabupaten Serang, Kota Banten dapat disimpulkan sebagai berikut:

1) Ibu balita di Desa Baros dan kader posyandu antusias mengikuti kegiatan penyuluhan kesehatan dari awal sampai akhir

2) Ibu balita dan kader mampu memahami materi penyuluhan dan mampu melakukan pemantauan pertumbuhan anak dengan menggunakan aplikasi di HP android yang pada akhirnya dapat mendeteksi secara dini terhadap risiko stunting pada anak.

\section{REFERENSI}

Dagne, S., jemal, A., Yonatan, M., Yosef, W., \& Netsanet, F. (2020). Determinants of Growth Monitoring and Promotion Service Utilization Among Children 0-23 Months of Age in Northern Ethiopia: Unmatched Case Control Study.

Daniel, B., Tesfaye, N., Mekonin, E., Kassa, A., Mensur, K., Zerihun, E., Deriba, K., Tadesse, H., \& Yeheyis, T. (2017). Knowledge and Attitude on Growth Monitoring and its Associated Factors among Mothers/Guardians of Children Less than Two Years in Areka Town, Southern Ethiopia, 2017. Journal of Nutritional Disorders \& Therapy, 07(03). https://doi.org/10.4172/2161-0509.1000216

Depkes. 2018. Cegah Stunting dengan Perbaikan Pola Asuh dan Sanitasi. https://www.depkes.go.id/article/view/18040700002/cegah-stunting-dengan-perbaikanpola-makan-pola-asuh-dan-sanitasi-2-.html

Devine, A., \& Lawlis, T. (2019). Nutrition and vulnerable groups. Nutrients, 11(5), 9-12. https://doi.org/10.3390/nu11051066

Direktorat Bina Gizi. (2011). Keputusan Menteri Kesehatan Republik Indonesia tentang Standar Antropometri Penilaian Status Gizi Anak. Depkes RI

Faqih. 2019. 32 kasus anak kurang gizi di kabupaten serang masuk 4 daerah tertinggi di banten. https://faktabanten.co.id/32-kasus-anak-kurang-gizi-di-kabupaten-serang-masuk-4daerah-tertinggi-di-banten/. Fakta Banten, Suara Merdeka Rakyat Banten

Hartono. (2016). Status Gizi dan Interaksinya. Http://Sehatnegeriku.Kemkes.Go.Id/. http://sehatnegeriku.kemkes.go.id/baca/blog/20170216/0519737/status-gizi-balita-daninteraksinya/

Hoffmann, R., \& Lutz, S. U. (2019). The health knowledge mechanism: evidence on the link between education and health lifestyle in the Philippines. European Journal of Health Economics, 20(1), 27-43. https://doi.org/10.1007/s10198-017-0950-2

Kementerian Kesehatan RI. (2011). Keputusan Menteri Kesehatan RI tentang Standar Antropometri Penilaian Status Gizi Anak. In Standar Antropometri Penilaian Status Gizi Anak (p. 40).

Kementerian Kesehatan RI. (2020). Pengendalian Stunting di Era Pandemi Covid-19. https://kesmas.kemkes.go.id/portal/konten/ rilis-berita/062215-kepmenkes-no-1995menkes-sk-xii-2010-tentang-standar-antropometri-status-gizi-anak

Peraturan Menteri Dalam Negeri No.114 Tahun 2014 Tentang Pedoman Pembangunan Desa

Tengkawan, J., Anandhika, A., John, R. E., Ihyauddin, Z., Jessica, K., \& Karuniawaty, T. P. (2020). Children Growth Awareness: An Important Role for Reaching the Optimal First 1000 Days in Life (Vol. 454, Issue Ecep 2019, pp. 146-150). Atlantis Press. https://doi.org/10.2991/assehr.k.200808.028

Yudrik Jahja. (2015). Psikologi Perkembangan (1st ed.). Prenadamedia Group. 